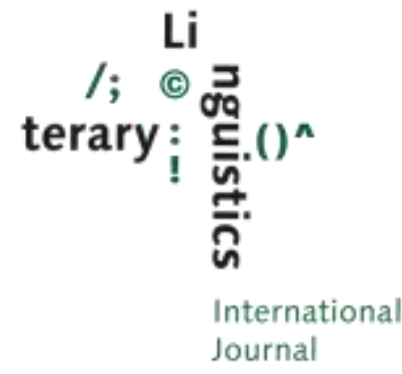

\title{
Authenticity, Boundaries, and Hybridity: Translating "Migrant and Minority Literature" from Swedish into Finnish
}

\author{
Simo K. Määttä, University of Helsinki
}

Keywords:

minor and

minority

literatures,

migrant writing,

Swedish

language,

Finnish

language,

authenticity,

hybridity,

boundaries,

focalization,

polyphony,

dialect,

sociolect,

critical

sociolinguistics,

translation

studies
Abstract: This article analyzes the representation of linguistic variation in the Finnish translations of four Swedish coming-of-age stories depicting migrant or minority perspectives: Mikael Niemi's 2000 Popular Music from Vittula, Jonas Hassen Khemiri's 2003 Ett öga rött, Marjaneh Bakhtiari's 2005 Kalla det vad fan du vill, and Susanna Alakoski's 2006 Svinalängorna. Through an analysis of speech and thought representation techniques and focalization, the article explores the role played by literature and translation in the materialization of dialects and sociolects as bounded entities. The paper argues that linguistic and social hybridity, on which the reception of minority and migrant literatures often focuses, is accompanied by the reification of new varieties conceived as authentic expressions of migrant and minority experience. Literature and translation are active agents in such processes, which are largely based on cultural, discursive, and cognitive constraints that condition the interpretation of each text.

\section{Introduction: Boundaries, hybridity, and authenticity}

The story of growing up between two or more cultures has been a popular theme in Western narrative fiction for decades. Perhaps the best known comingof-age story of this kind is Zadie Smith's White Teeth (2000), although predecessors have appeared since at least the early 1980s, for example in France (Mehdi Charef's Le Thé au harem d'Archi Ahmed, 1983) and in Sweden (Finland-born Antti Jalava's Asfaltblomman, 1980). Such themes are not new: for example, African-American authors such as Richard Wright (Black Boy, 1945), James Baldwin (Tell Me How Long the Train's Been Gone, 1968) and Toni Morrison (The Bluest Eye, 1970) have explored them. Recently, coming of age between two (or several) cultures has also become a popular motif in Scandinavian literature, especially in Sweden.

The linguistic, thematic, and narrative similarities between different coming-ofage stories focusing on migrant or ethnic minority experience suggest that these novels form a distinct genre. The most important linguistic feature of this genre is abundant variation in sociolect and register in the representation of the characters' speech and thought, as well as in the narrator's discourse. Thematically, this variation is often interpreted as an intrinsic characteristic and 
manifestation of hybrid identities: the characters of the novel, especially the protagonist, appear to navigate between two or more ethnic and social identities, in particular between a majority identity and a minority identity. The exploitation and perception of boundaries between different languages and language varieties and their blurring, resulting in hybridity, therefore constitutes one of the essential features of this novelistic genre.

The perceived hybridity on the level of language and identity is linked to narrative techniques. Thus, first-person narratives in particular (the most common narrative framework employed within this genre) are often read as (pseudo)-autobiographies because the narrator and the protagonist are conflated (Genette 1972: 214, 236; 1982: 71), and because readers have a natural tendency to conflate the author with the narrator (Gavins 2007: 129). However, classical third-person narratives belonging to this genre may receive a similar reading. Therefore, it appears that an essential criterion for genre membership is that the author is familiar with the social and linguistic world depicted in the story. Otherwise, the representation of that universe would not be authentic - the author would appear to be unreliable (cf. Cohn 2000). Hence, authenticity emerges as another key concept when analyzing this genre.

This article examines authenticity, hybridity, and boundaries in four Swedish novels belonging to this genre and their Finnish translations. The emphasis is on the analysis of the relations between the protagonist, narrator, and author. First, I will provide a brief overview of the ways in which the translation of nonstandard language in narrative fiction has been treated in previous research in translation studies and beyond. Second, I will analyze the representation of sociolinguistic variation in the Swedish source texts and in Finnish translations of Mikael Niemi's Populärmusik från Vittula (2000, also published in English as Popular Music from Vittula in 2003), Jonas Hassen Khemiri's Ett öga rött (['One Eye Red'], 2003), Marjaneh Bakhtiari's Kalla det vad fan du vill (['Call It Whatever You Want' or 'I Don't Give a Fuck What You Call It'], 2005), and Susanna Alakoski's Svinalängorna (['Swine Projects' or 'Swine Rows'], 2006). This analysis, which focuses mainly on speech and thought representation, is necessarily a linguistic one. Third, I will examine the ways in which the protagonist, the narrator, and the author may be approached using the narratological concept of focalization or point of view. Since the concept of focalization is not linguistic per se (although focalization is of course created linguistically), this analysis will be more succinct than the linguistic analysis of speech and thought representation. To conclude my article, I will analyze whether the concepts of hybridity, boundaries, authenticity, and polyphony are useful in explaining both the emerging genre of multicultural coming-of-age stories in Sweden and some of the translation strategies that can be observed in Finnish translations of novels belonging to this genre. The goal of the article is not to criticize the translations or the translators, who demonstrate excellent analytical, stylistic, and creative ability.

The concepts of authenticity, hybridity, and boundaries link the analysis to contemporary sociolinguistics and linguistic anthropology (see e.g. Coupland 2014; Heller \& Duchêne 2014; Heller 2014; Pietikäinen \& Dlaske 2013), in which 
concepts familiar from variationist sociolinguistics, such as speech community and native speaker, as well as the epistemological foundations of linguistics and sociolinguistics, have been problematized and questioned. The concept of polyphony connects the analysis to text linguistics and the theory of argumentation and énonciation. Thus, I will discuss the inherent polyphony of utterances, texts, and language use in general - polyphony in the sense of multiple possible voices, sources or loci of discursive responsibility, and contexts (see Halliday 1978: 31; Ducrot 1980). This discussion will focus on the potential consequences of our ability or inability to interpret polyphony.

Among other things, the article aims at providing interfaces between linguistic approaches to variation on the one hand - such as those conceptualized within narratology and translation studies - and contemporary sociolinguistic and textlinguistic theory on the other. Indeed, a formalist linguistic or pragmatic analysis would not suffice to answer why this particular novelistic genre has emerged and how and why certain translation strategies related to this genre can be identified.

\section{Translating non-standard language}

By definition, spoken language cannot be reproduced in written form: we use letters, punctuation, and typographical devices to stylize our writing, but we cannot write sounds, intonations, or pauses, not to mention the situational, social, and intertextual context in which spoken utterances are produced. Consequently, narrative fiction can only index and evoke the characteristics of spoken language and constitute a representation rather than a reproduction of spoken language. Means used to do this include word order, orthography, punctuation, and narrative report of speech act (see Leech \& Short 1981: 323 for this term, which is not related to speech act theory, referring to passages in which the narrator tells what the characters said and how). In many languages, there is a long tradition of written representation of spoken language. Thus, when characters in a novel speak (and think) in a way that corresponds or is close to what is conceived as the norm of standard written language, their speech and thoughts appear to be reproduced faithfully because we think that the norm of standard language is identical in writing and speech. But this is only an illusion of mimesis.

The issue is much more complex when the language use of a character or the narrator is not standard and appears to represent a distinct regional dialect, sociolect, ethnolect, idiolect, or even a foreign language, for there are few conventions for the written representation of such varieties. During the $20^{\text {th }}$ century, the representation of sociolinguistic variation has become so common in Western literature that its presence has been normalized to a certain degree (Fludernik 1996: 71). Many terms have been proposed to theorize this variation: literary sociolects (Lane-Mercier 1997: 46-47), standard vs. non-standard literary dialect (Määttä 2004), and heterolingualism (as opposed to sociolinguistic variation and multilingualism in the "real world" Grutman 2006: 18). Linguistic hybridity (reflecting multilingualism) in the novel has also been 
analyzed as pertaining to different categories of translation on the part of the character or the narrator and divided into symbolic hybridity, in which language is only a medium, and iconic hybridity, in which language as a medium and object are the same (Klinger 2015: 16-23).

As scholars such as McHale (1994), Lane-Mercier (1997: 46), Ramos Pinto (2009: 290), and Taivalkoski-Shilov (2006: 48) note, the representation of social and regional variation is based on stereotypes and assumptions about sociocultural and linguistic differences that people recognize by a minimal number of differentiating markers. This representation is always related to ideologies, i.e. sets of values, and especially language ideologies, i.e. cultural conceptions of the nature, purpose, and function of language (Gal \& Woolard 1995: 134; Woolard \& Schieffelin 1994). In this sense, language use and its representation is never neutral: it is impossible to use language without simultaneously conveying attitudinal information (Fowler 1977: 76). All linguistic units and varieties can therefore be conceived not only as having a communicative function but also an indexical function: they index social phenomena such as group membership and identity. These indexicalities, i.e. hierarchically structured, stratified, and primarily local sociocultural dimensions of meaning, can be conceived as "projections of functions onto form" (Blommaert 2006: 164165; Silverstein 1979). In other words, when sociolects, dialects, and registers are represented in literature, the linguistic forms of which they are composed are recognized as referring to a given sociocultural group and/or identity. However, this representation does not constitute a verbatim reproduction of actual speech. Thus, the representation of sociolinguistic variation in a novel does not reflect real language use; it refracts it, and this refraction is always ideological (Blommaert 2006: 173) because it is based on values and beliefs (and sometimes stereotypes) related to individuals and groups. This representation is sociocultural: although the basic meaning of the forms used in this representation may be relatively stable, they acquire different indexical meanings depending on their social and cultural context, including the specific contexts that are activated when a reader reads and interprets the text.

Consequently, translation is always a process of re-contextualization (House 2006), i.e. a transcription of a source text into a new context, because indexicalities and sociocultural dimensions of meaning differ from one language and culture to another, from one language variety and sub-culture to another, from one situation to another, from one reader to another, from one era to another. Naturally, some of these indexicalities and sociocultural meanings, which are part of the context, are shared. Otherwise, translation and indeed communication would be impossible. However, the contexts within which readers of a text operate can never be identical, and they are even more likely to be different if we compare readers who read the source text and those who read the target text: their initial contexts are different, and the contexts activated by the text cannot be exactly the same in different language versions. Each version has its own order of indexicality contingent upon the culture(s) related to that particular language because each text and each word and construction composing a text has its own order of indexicality. 
Hence, orders of indexicality related to the representation of sociolinguistic variation are part of the context that is transformed in translation. Indeed, for the literary translator, non-standard language constitutes an important challenge, and its translation is often characterized as an impossible task (see e.g. Folkart 1991: 343; Lane-Mercier 1997; Sánchez 1999; Ramos Pinto 2009: 291). However, non-standard language in the novel has to be translated. The concept of translation strategies is a useful tool for analysing such translations.

Translation strategies depend on time and language-contingent factors such as translation norms and translation culture (see Ramos Pinto 2009 for a comprehensive survey of strategies identified in previous literature). A common strategy used in the translation of non-standard language use has been to look for an equivalent variety in the target language, but this strategy usually alters the narrative, social, and ideological constellation (see e.g. Berman 2000 [1985]: 286; Berthele 2000; Määttä 2004). In other words, while the goal of this strategy is to create a context that is similar to the source text, the new context in fact takes the target text even further from the original context than a more neutral strategy, effacing hybridity, would do. This is why other strategies such as those based on the analysis of the function of the variation have been proposed (Hatim \& Mason 1997: 97-109). However, as will be shown later, the search for authentic equivalence is still common, both among literary critics and translators. Besides, the variety-to-variety approach seems to function quite well in cases in which it is assumed that the social stratification of the two cultures is similar enough, and when there is a solid tradition of literary representation of non-standard language in the target culture. Examples include translations of drama in Quebec and Scotland (Brisset 1990; Findlay 1996).

Thus, non-standard language in translation is also related to the cultural distance between the source text and the target text, i.e. the cultural fidelity of the translation or the spectrum of integrating vs. alienating translations, discussed by Schleiermacher (1963) as early as 1813. House (2006: 437) analyzes the same phenomenon in terms of overt and covert translations and Venuti $(1995,2000)$ within the domestication-foreignization dichotomy. Venuti's terminology is widely used in translation studies today, and he has identified domestication rather than foreignization as a typical feature of translations of world literature into English. The domestication-foreignization dichotomy is inherently political - foreignization is a strategy through which minor literatures as well as linguistic and cultural heterogeneity can be acknowledged within the target culture. But such foreignization can also become a double-edged sword and a tool for a new, subtler exoticism, just as any other discursive strategy may (Buzelin 2006: 104; cf. Arrojo 1994: 159-60; Lane-Mercier 1997: 64). Moreover, the situation is quite different when the direction of translation is towards a minor literature such as Finnish literature (Paloposki and Oittinen 1998): since the source text typically comes from a major culture, the acknowledgement and empowerment or the exoticization of the minor culture represented by the source text are not at stake.

The texts analyzed in this article, however, constitute a special case because the source texts represent not only a majority culture but also cultural heterogeneity and minority cultures. One could argue that a text never 
represents just one culture and its values. This is particularly true when considering the novel, for as Bakhtin (1986) has shown, one of its characteristics is the ability to represent different ideological viewpoints and stances.

The translation of a text that is linguistically and narratively hybrid can therefore provide interesting insights into the interpretation of the function and meaning of linguistic variation and the impact of translation strategies on the ideological structure of the novel. In fact, translations provide evidence of the text's take-up, i.e. reader-response (Mason 2014: 52), and have heuristic value (Buzelin 2006: 95). For example, translations inform us about the ways in which the translator has interpreted the function of linguistic variation. In the following sections, this heuristic value will be explored through an analysis of four Swedish novels into Finnish. Section 3 provides a linguistic analysis of voices in the four novels. The analysis of the first novel requires more space because it introduces many of the concepts used throughout the analysis. Section 4 expands the analysis to the narratological concept of focalization. Discussion and links to contemporary sociolinguistic theory through the concepts of authenticity, boundaries, hybridity, and polyphony follow in subsequent sections.

\section{Analysis of the representation of sociolinguistic variation}

\subsection{Popular Music from Vittula}

Mikael Niemi's Populärmusik från Vittula was published in 2000 in Sweden and received the prestigious August prize the same year. Subsequently, the novel was translated into several languages, including Finnish (2001) and English (2003). The novel is particularly rich from a sociolinguistic point of view: language variation and diglossia are not only prevalent in the language use represented in the novel but also constitute some of its main themes. The story covers the main character's school years in Northeastern Sweden, on the Western bank of Torne River, which forms the border between Finland and Sweden in the North. The local population lives in a bilingual and diglossic situation: Swedish, on the one hand, and Torne River Valley Finnish or Meänkieli ('our language'), on the other. The language of the dialogue is often specified in narrative reports of speech acts (in the sense Leech and Short use this term) such as "he said in Finnish" or "I said in Finnish to make sure he understood." The first-person narrator also reflects upon language use and the sense of estrangement and otherness he and his peers feel because they think that they speak neither Swedish nor Finnish correctly. Furthermore, the novel represents the process of language attrition, whereby the main characters gradually use Meänkieli less frequently as they grow up and eventually move to Southern Sweden in search of more secure employment.

Other languages are present as well: the main character's best friend, whose family is also Meänkieli-speaking, does not utter a single word, although he understands Finnish. However, at one point it turns out that he has miraculously learned Esperanto and speaks it fluently. There is also a German-speaking 
character, as well as a group of English-speaking relatives visiting from America. In addition, when the protagonist discovers popular music, English and the representation of English pronunciation by the local youths emerge in the text. Therefore, language is also one of the themes orienting the narration towards magical realism that is typical of this book. Thus, while the minority language situation and the diglossic relation between Meänkieli and Swedish is seen as shameful, multilingualism is also a source of enrichment and a resource, providing the characters with secret wisdom that monolingual speakers and readers do not have. The way in which Meänkieli is present in the text exemplifies this esoteric dimension of language use particularly well.

In the source text, Meänkieli appears mostly in the direct speech of the characters, older secondary characters in particular. These utterances, expressions, and words are typically related to local culture. They are italicized and glossed verbatim in Swedish. In the instances in which Meänkieli appears, the rest of the dialogue is in Swedish. At least two hypotheses can be proposed regarding the communicative function of utterances in Meänkieli. If the communicative function of these utterances is to signal that the language of the diegesis is in fact Meänkieli rather that Swedish, the narrator functions as a translator, which would indicate narratorial control of the characters' speech and thoughts. But if the function is to signal that the language of the diegesis is a mixture of Swedish and Meänkieli, the narrator merely transcribes the characters' speech as it is and delegates control to the characters.

Furthermore, the interpretation of the communicative function of this bilingualism depends on the languages the reader knows: a reader who does not know Finnish or Meänkieli does not necessarily know that the utterance in Meänkieli is a verbatim reproduction of the utterance in Swedish (or English in the English translation). In contrast, a reader who knows Finnish or Meänkieli sees a repetition of the Swedish utterance in Meänkieli (if the reader regards Meänkieli as a discrete language) or a dialect of Finnish (if the reader thinks that Meänkieli is a dialect of Finnish).

In the Finnish translation, most utterances in Swedish are translated in standard Finnish, whereas utterances in Meänkieli are reproduced verbatim. As a result, bilingualism between two mutually unintelligible varieties (Meänkieli and Swedish) becomes bilingualism between two (mostly) mutually intelligible varieties (Meänkieli and Finnish). If the Finnish or Meänkieli-speaking reader thinks that the presence of Meänkieli indicates that the diegesis in fact happens in Meänkieli, the narrator appears to be translating the speech of the characters while controlling that speech. But if the reader interprets the passage as an instance of mixing the two codes, the narrator appears to be delegating some of that control to the characters. The interpretation therefore has an influence on the distance perceived between the narrating "l" and the characters, the experiencing "l" in particular.

Bilingualism between two mutually unintelligible varieties and the estrangement created by the foreign language are therefore inevitably lost in the Finnish translation. But the translation attempts to remedy this loss by extending non- 
standard usage even to places where the source text is standard. The following passage, which depicts the particular beliefs of the Laestadianist revivalist movement in free direct speech, shows that the translator therefore seems to have opted for the interpretation according to which utterances in Meänkieli indicate that the language of the diegesis is in fact Meänkieli rather than Swedish:

1a) Vid jordfästningen ropar predikanterna at du dog i den levande tron. Saken är klar. Du dog i den levande tron, sie kuolit elävässä uskossa. Du kom till Muodoslompolo, vi har alla bevittnat det, och nu sitter du äntligen på Herren Gud Faders gyllene pakethållare i den eviga, änglatrumpetande nedförsbacken. (Niemi 2000: 23)

1b) At the funeral the preacher bellows on about how you died in the living faith. No doubt about it. You died in the living faith, sie kuolit elävässä uskossa. You got to Muodoslompolo, we all witnessed it, and now at long last you are sitting on God the Father's golden luggage carrier, freewheeling down the eternal slope accompanied by fanfares of angels. (Niemi 2003: 23)

The italics marking non-standard lexical items in the Finnish text are mine:

1c) Hautajaisissa saarnaajat hehkuttavat, että sinä kuolit elävässä uskossa. Asia on täysin selvä. Sie kuolit elävässä uskossa. Sinä pääsit Muodoslompoloon, me kaikki olemme todistaneet sen, ja nyt istut viimeinkin Herran, sinun Jumalasi kultaisella pyöränhollarilla ja huilaat enkeltrumpettien pauhussa ikuista alamäkeä. (Niemi 2001: 25)

But the foreign element that appears to be a translation also functions as a door to the inner circles of the diegesis, marking a change in the narratorial control of reported speech. The beginning of this passage is attributed to the narrating "I" (possibly followed by interior monologue of the experiencing "I" in "No doubt about it") and continues in free direct speech attributed to an unidentified revivalist preacher. The first non-standard word in the translation is the subject pronoun sie 'you' (in standard Finnish sinä), which is a strong marker of most Northern and Eastern dialects of Finnish and also appears in the same form in the source text. But two subsequent nouns (pyöränhollarilla, enkeltrumpettien) and one verb (huilaat) are also non-standard in the translation. The first noun can be associated with Northwestern dialects because of the Swedish loanword in the second part of the compound. For the second noun, the association with a particular dialect or any non-standard variety is not clear - in fact the omission of the final $-i$ of the first part of the compound links the word to a famous Christmas carol and religious contexts on the one hand, and to a type of flower on the other. As for the verb, it represents regionally unmarked non-standard Finnish, although the transitive usage is rather idiosyncratic. Both forms could also be regarded as somewhat archaic.

While the source text is hybrid because it is bilingual, the Finnish translation is therefore a hybrid because it is a mixture of standard Finnish, unmarked nonstandard, non-standard marked as a representation of Northwestern dialects, 
and non-standard marked in a way that cannot be identified in a precise manner. As suggested above, an attempt to remedy the loss of the representation of multilingualism is a plausible explanation for the increased non-standard features of the Finnish text. But the fact that the preacher's free direct speech is rendered somewhat ironic by the metaphors of the source text (luggage carrier; angel trumpets used idiosyncratically as a deverbal adverb "angel-trumpeting") may also have influenced the increased dialect representation in this passage. In any case, intensified non-standard marking in this passage increases the distance between the narrating "I" and the unidentified secondary character.

Accentuated non-standard representation in the translation is particularly visible in passages in which the characters' utterances are rendered in direct speech. In these instances as well, although there are scattered utterances in Meänkieli glossed in Swedish in the source text, the representation of non-standard, in this case clearly Meänkieli or North-Western Finnish dialect, spreads to other utterances of the same dialogue. This increased non-standard representation concerns even utterances that are standard (yet marked as representations of colloquial usage by means such as elliptical sentences) in the source text. Typically, one line of a secondary character's utterance in Meänkieli text triggers dialect representation extending to the rest of this character's and also other characters' speech in a given passage of the translation. For example, in the following passage, the main character is about to be molested by an older man (who has just magically turned into an older woman). The utterance in Meänkieli is italicized in the Swedish and the English text; the italics of the Finnish text are mine:

2a) - Hålla lite..., bara känna lite...

Plötsligt hade jag hans spetsnaglar i ryggen. De började trippa som klor, nedåt mot midjan.

- Hiiri tullee... Råttan kommer...

$\ldots$

- Vi klarade oss! skrek jag genom motordånet. (Niemi 2000: 101-102)

2b) - Just hold me a bit... Just touch me...

Suddenly I could feel his sharp-pointed nails on my back. They started tripping down towards my waist. Like claws.

- Hiiri tullee... Here comes the mouse...

$\cdots$

- We made it, I yelled over the roar of the engine. (Niemi 2003: 102-103)

2c) - Mie vähän pitelisin... kokkeilisin vähän.

Yhtäkkiä tunsin hänen terävät kyntensä niskassani. Ne alkoivat liikkua kevyesti ja varovasti kuin pedon kynnet, alaspäin kohti vyötäröä.

- Hiiri tullee...

$\ldots$

- Met selvisimmä siittä! minä karjuin moottorin jyrinän yli. (Niemi 2001: 115116)

In summary, bilingualism (and diglossia) between two languages in the source text becomes bilingualism between two varieties, standard and dialect, in the 
Finnish translation, and dialect representation spreads towards utterances that were not marked as foreign in the source text. This strategy appears to constitute an attempt to remedy the loss of bilingualism and alterity resulting from the fact that Finnish readers understand Meänkieli and interpret it as a Finnish dialect rather than as another language. In the target text, the increased morphological and lexical representation of dialect therefore favors the interpretation that events and experiences in the diegesis are thought and spoken in Meänkieli, i.e. non-standard. In fact, no translation strategy would have reproduced the sociolinguistic constellation of the source text faithfully. While this accentuated dialect representation also concerns utterances produced by the protagonist, it increases not only the distance between the narrator and the secondary characters, but also the distance between the narrating and the experiencing "I".

\subsection{Ett öga rött}

Jonas Hassen Khemiri's Ett öga rött was published in 2003, and the Finnish translation came out the following year. The novel is written in the form of a diary exposing the thoughts and deeds of a ninth-grader born in Stockholm of Moroccan parents and living with his father. The story covers one semester of the protagonist's life, although there are also flashbacks to previous events, especially events related to his late mother. The novel's universe is immersed in sociolinguistic variation: the character's father speaks Arabic with his friends and alternates Arabic and Swedish when communicating with his son.

Occasionally, there are entire utterances or single words or short expressions in Arabic. On several occasions, the narrator specifies whether a given utterance was originally in Arabic or in Swedish. Furthermore, there are reflections about the diglossic quality of the Arabic language, as becomes apparent in the coexistence of different accents and the difference between classical written Arabic and spoken varieties. There are also many comments concerning the diglossia between standard Swedish (depicted by wordings such as "nerdy Sven language" or "Sven tone") and the colloquial variety used by the main character. On one occasion, the protagonist's father sees his diary and makes furious comments about the bad quality of his Swedish, wondering why the son has started to use such poor language although just a few years earlier "his Swedish was perfect."

In this novel, non-standard language is not limited to occasional instances of speech and thought representation: it is present throughout the book and in the narrator's language use in particular. The most salient feature is word order: in subordinate clauses and following an adverbial at the beginning of a clause, the narrator uses the S-V constituent order instead of the reversed order, V-S, which would be the norm for standard Swedish in these cases. Other features are lexical, such as English words, slang words, and expressions borrowed from languages of immigration such as walla, 'I swear (to God)'. There are also expressions calqued on other languages (e.g. jag lovar, 'I swear', calqued on walla). Many of the non-standard lexical items are swearwords (knulla, 'fuck'), words that have become emblematic of the so-called "immigrant Swedish" such 
as guss ('girl', borrowed from Turkish kız; see Milani 2010: 127), and/or derogatory terms related to sexual minorities and ethnic groups. However, gays, Swedes, and Jews are not the only groups addressed by derogatory terms: there are also disrespectful comments on (dark-skinned and/or dark-haired) foreigners, such as svartskalle and blatte.

In the Finnish translation, lexical and typographic means are used to render the non-standard flavor of the source text. Lexical means include Finnish swearwords, vulgar terms related to sexual activities, and slang words depicting persons and groups of people. The translation also uses non-normative punctuation, omitting most commas. But there are attempts to reproduce the word order of the source text in the translation, as shown in the following example ( $m y$ italics in all language versions):

3a) Nästan han hade ringat in mig i hornet (och skulle ångrat sig länge) om inte Alex kommit till hans räddning. (Khemiri 2003: 40)

Almost had he cornered me (and he would have had to regret it for a long time) if Alex did not come over to help him.

3b) Melkein hän oli saanut minut ajetuksi nurkkaan (ja olisi joutunut katumaan pitkään) kun Alex saapui pelastamaan. (Khemiri 2004: 40)

Finnish and Swedish are structurally quite different languages, and their rules governing word order are not the same. In Finnish, this word order is not ungrammatical, although it is unusual. At the same time, it is not linked to any particular sociolinguistic or regional variety. On other occasions, this strategy of translating the word order creates a specific meaning. For example, placing the adverb vähän 'a little' at the beginning of the utterance usually means 'a lot' in colloquial Finnish:

4a) Lite hon ger bilden av en klassisk arabisk filmstjärna --- (Khemiri 2003: 123)

A little does she look like an Arabic movie star.

4b) Vähän hän näyttää samalta kuin klassiset arabialaiset filmitähdet, --(Khemiri 2004: 123).

The translation of absolute superlatives accentuates the impression that there is, in addition to the narrator-as-a-character using non-standard language, another narratorial instance using a more standard version of Swedish, and the two become entangled. Both in the Swedish and the Finnish text, the absolute superlative is accompanied with non-standard lexical features. Absolute superlatives are not indexed as colloquial in Finnish. Therefore, the voice of the narrating "l" becomes more salient in the translation because in Finnish the absolute superlative pertains to literary registers of language use:

5a) Eftersom jag vet hur dom tänker jag använde töntigaste svennetonen. (Khemiri 2003: 165)

Since I know how they think, I spoke using the nerdiest Sven tone. 
5b) Sen takia että tiedän mitä he ajattelevat puhuin mitä nössöimmällä sveduäänellä. (Khemiri 2004: 166)

In this translation as well, a faithful rendering of the sociolinguistic dimension of the source text would have been impossible. Here, the translation strategy consists of rendering non-standard forms and constructions in the source text with non-standard forms and constructions in the same places in the target text. But since the indexical dimension of these elements is inevitably different in the source and the target text, the strategy triggers changes affecting the narrator. Thus, the image of the narrator-character is slightly different in the translation, and the distance between the narrating "I" and the experiencing "I" appears to increase. In fact, the source text emphasizes written representations of colloquial language and reads as a sort of transcript of utterances that can be imagined as spoken or thought. But the translation reads more as a traditional first-person narrative, a representation of idiosyncratic writing or thought in which standard language is combined with slang words, incorrect punctuation, and an unusual mixture of registers.

\subsection{Kalla det vad fan du vill}

Marjaneh Bakhtiari's Kalla det vad fan du vill was published in 2005 in Sweden and translated into Finnish in 2007 (see also Liisa Tiittula's and Pirkko Nuolijärvi's article in this special issue). The main character, Bahar, is 9 years old when her family moves from Iran to Malmö in Southern Sweden. The story ends when she is 24 years old. While the narrator uses the third person rather than the first person which is the default narrative mode for a coming-of-age story, the theme and the temporal convergence between the diegesis and the time of the narration at the end of the novel (Genette 1983: 233) mark the novel clearly as a Bildungsroman.

Linguistic variation occupies a central position in this text. Standard Swedish, Swedish youth slang, old Scanian (Skåne) dialect and modern Scanian accent, Swedish spoken by first-generation migrants, English spoken by a Swede, Jamaican English, Spanish, and Farsi are represented in the direct speech of the characters. In addition, there are metalinguistic comments throughout the novel: in conversations between the characters (adult migrants talking with their children, adults trying to learn Swedish among themselves) and in mixed forms of speech and thought representation. Language is also a typical topic of narrative reports of speech acts (in Leech's and Short's understanding of the notion).

Generally, standard Swedish is used in the narration, in the speech representation of some of the secondary characters, as well as in dialogues in which Farsi (and occasionally Arabic) is used in the diegesis. Occasionally, words or short phrases in Farsi appear in dialogue, and idiosyncratic syntactic features sometimes suggest a different speech style related to Farsi. Spelling evoking a non-standard pronunciation and eye dialect (i.e. spelling indexing non-standard language without indicating any specific non-standard pronunciation, e.g. dont vs. don't) are used to represent accent, regional dialect, 
and Swedish spoken by adult migrants. Youth slang characterized by English words and expressions, often vulgarisms used as ritual insults, is a typical speech pattern of the protagonist's brother and sometimes also the protagonist.

A mixed strategy can be observed in the translation: some utterances are translated using the dialect-for-dialect approach at varying degrees of intensity, others by adjusting the spelling and eye dialect which evokes non-standard pronunciation and Finnish stereotypes of different accents. Morphosyntactic means are also used. Thus, "broken Swedish" is rendered by features typically associated with "broken Finnish," such as the inability to distinguish between short and long sounds and a simplified system of case endings and verb conjugation. Some of these means are exemplified in the following passage, in which Bahar's parents are attending a parent-teacher conference at Bahar's school. The teacher has just explained that Bahar is a good student and that there have not been problems with any teachers or students. Bahar's father has not understood a word, whereas her mother has only identified the words Bahar, teacher, and problem:

6a) - Vi är... peroblem? Bahar? Inte. Nej. Micke esnell. (Bakhtiari 2005: 20)

- We are... problems? Bahar? No. No. Very nice.

6b) - Me olemme... ong-gelmia? Bahar? Ei. Khhyvin kilti. (Bakhtiari 2011:

26)

In Swedish, the mother's speech is characterized by the inability to pronounce certain consonant clusters ( $p r$ in problem and sn in snäll [esnell in the mother's speech]), sentences without a verb, and altered vowel quality (micke instead of mycket and esnell instead of snäll). The omission of the final - $t$ in micke appears to indicate eye dialect. The translation uses partly similar means (verb omission in Khyvin kilti). The spelling of ong-gelmia 'problems' instead of ongelmia suggests a pronunciation in which the nasal velar sound is followed by a plosive, and the spelling of khyvin 'very' instead of hyvin evokes a velar instead of glottal pronunciation of the fricative $h$ sound. In addition, the gemination in kiltti ('nice') becomes a short consonant (kilti). This passage is also an example of the way in which standard and non-standard speech can be alternated in fictional dialogues to an amusing effect.

The parody of politically correct and diversity-loving liberals is a key theme in the novel. Thus, Pernilla, the mother of Bahar's boyfriend Markus, is characterized as indulging in books written in "broken Swedish," "new Swedish," "immigrant Swedish," and different varieties of "suburban Swedish." In the following excerpt, she is using the word gus, an "immigrant Swedish" word she has learned from a book. (The word can be spelled either guss or gus.) At the same time, this passage is one of the many examples of the way in which Swedish people constantly mispronounce the main character's name (Baha instead of Bahar):

7) - Jag tycker verkligen att du är en jättetrevlig gus, Baha.

- Va?

- Ja, haha, jag har lärt mig lite nya ord och förstår du. Gus, du är en soft 
gus. Eller säger jag det fel kanske? Vänta, jag ska hämta boken, men jag tror jag sa rätt. --- (Bakhtiari 2005: 168)

- I think that you are a really nice gus, Baha.

- What?

- Well, haha, I have learnt a few new words and you know what I mean.

Gus, you are a soft gus. Or am I mispronouncing it perhaps? Wait, I'll get the book, but I think l'm saying it right. ---

These lexical items representing "immigrant Swedish" are kept as they are in the Finnish translation.

Mixed categories of speech and thought representation, such as free indirect discourse, are usually marked by typographical devices such as italics. Other instances of free indirect discourse, which are under the narrator's control, appear to have an ironic purpose, as exemplified in this passage which is related to the previous example and describes Pernilla's leisure activities as chilling out. In these instances italics are not used:

8a) När Pernilla inte chillade med några sköna böcker från ghettot slogs hon för bättre cykelbanor i stan. (Bakhtiari 2005: 168)

When Pernilla was not chilling out in the company of nice ghetto novels, she was fighting for better bicycle paths in the city.

8b) Ja silloin kun Pernilla ei chillannut kivojen gettokirjojen seurassa, hän taisteli parempien pyöräteiden puolesta. (Bakhtiari 2011: 246)

While some of the humor and the irony may disappear in this translation, there are no major shifts affecting the relations between the narrator and the various characters. This could be related to the fact that the wide array of different varieties is such a salient feature of this novel. In addition, boundaries between different varieties and their connections to the characters and the narrator are exceptionally clear. Therefore, the text appears to be not only heterolingual but also essentially polyphonic in the traditional sense of the term (Bakhtin 1986), i.e. presenting multiple voices and ideological viewpoints alongside each other.

\subsection{Svinalängorna}

Susanna Alakoski's Svinalängorna covers ten years in the life of the main character, whose family has moved from Finland to Sweden and lives in a public housing project that the locals call Swine Projects because of the social problems concentrated there. The novel was published in 2006 in Sweden and won the prestigious August prize the same year. The translation in Finnish, Sikalat, came out the following year.

The novel's diegesis is bilingual: the protagonist's parents mostly speak Finnish at home and with their Finnish-speaking friends. They also speak Finnish with their children, although gradually the children start using Swedish. The mother's and especially the father's Swedish pronunciation are occasionally marked by spelling that mimics their phonetic properties. Finnish is more present in the first 
part of the novel and disappears as the protagonist grows up and the parents gradually become alcoholics.

The retrospective first-person narrator's voice is often mixed with the voices of other characters, the mother in particular, through techniques such as free direct discourse. Finnish words and utterances are mostly swearwords used as interjections and insults appearing in the adults' speech, often in scenes in which the parents are arguing and drinking. The following example is extracted from such a scene, which takes place on Christmas Eve. The father has been drinking for several days and is now behaving violently. I have italicized the Finnish utterances in the Swedish text and the corresponding utterances in the translations.

9a) Pappa svor och vrålade ute på gården. Vad skulle hända nu?

En stor sten krossade vår mittruta, vädringsfönstret. Blomkrukan for ner på golvet, glassplittret flög ut i rummet. Sakari skrek till, jag började panikgråta. Markku sa inte ett ord men han hade jättestora ögon.

Voi hevon vittun (sic) vittu, sa pappa.

Mamma stängde av teven.

Voi saatanan saatana. Sedan småsprang mamma till hallen och låste upp dörren. Pappa kom i med knutna nävar. Fan ta den som sa något dumt nu. (Alakoski 2006: 103-104)

Daddy swore and was shouting on in the courtyard. What would happen now?

A big stone hit our middle window, the ventilation window. The flowerpot fell onto the floor, debris of broken glass flew into the room. Sakari screamed, I started to cry in panic. Markku did not say a word but his eyes were wide open.

Voi hevon vitun vittu, Dad said.

Mom turned off the tv.

Voi saatanan saatana.

Then mom rushed into the hallway to open the door. Dad came in with fisted hands. God help the one who said something stupid now.

9b) Isä kirosi ja karjui pihalla. Mitä nyt tapahtuisi?

Iso kivi rikkoi keskimmäisen ikkunan, tuuletusikkunan. Kukkaruukku putosi lattialle, lasinsirua sinkoili huoneeseen. Sakari parkaisi, minä aloin hädissäni itkeä. Markku ei sanonut sanaakaan mutta hänen silmät olivat pyöreät.

- Voi hevon vitun vittu, isä sanoi.

Äiti sulki telkkarin.

- Voi saatanan saatana.

Sitten äiti kipitti eteiseen avaamaan oven. Isä tuli sisälle kädet nyrkissä. Auta armias sitä joka sanoi jotakin tyhmää. (Alakoski 2007: 113)

Finnish words are not glossed in the source text because they are quite similar in Swedish and Finnish (e.g. Finnish vittu, Swedish fitta, 'cunt', and Finnish saatana, Swedish satan, 'Satan', both used as interjections). Besides, these words and the interjection voi 'oh' have previously appeared several times in the adult Finnish-speaking characters' speech, starting from the first paragraph of the novel. This passage also exemplifies the shifts affecting categories of 
speech and thought representation in the translation. Thus, the fact that the father speaks Finnish suffices to distinguish these voices in the source text. In the Finnish text, this difference disappears, which is probably the reason why the father's free direct speech has been transformed into direct speech. In passages preceding this one, free direct speech is attributed mostly to the mother: if free direct speech were maintained, some of this profanity would potentially be attributed to the mother.

Profanity and short sentences, often consisting of one single clause in the speech of the characters, give the text a colloquial flavor. This may have motivated enhanced colloquial marking of the narrator in the translation (for example the omission of the possessive suffix -nsä in (hänen) silmät ['his eyes'] in the previous example). But structural differences between Finnish and Swedish also play a role. Indeed, in addition to non-normative punctuation, the translation systematically uses the passive form for all first-person plural forms of verbs, which is the norm in most varieties of colloquial Finnish. Using this device to render the text less standard is a relatively neutral choice, for it is not linked to any particular dialect or sociolect. I have italicized the first-person plural forms in the following example which also shows how the translation combines colloquial passive verbal forms with lexical (ääreen) and morphological (possessive suffix -mme in viereemme) features typical of literary, written language:

10a) Vi tog varsin sovsäck och satte oss på dem vid eldstaden. Vi ställde väskorna med choklad, godis, smörgåsar, cigaretter och tårta bredvid oss. (Alakoski 2006: 258)

We took each our sleeping bags and sat beside the campfire. We placed our bags, in which we had chocolate, candy, sandwiches, cigarettes, and cake, next to us.

10b) Me otettiin makuupussit ja mentiin nuotion ääreen istumaan. Me pantiin viereemme laukut, joissa suklaa, karkit, voileivät, tupakat ja täytekakku olivat. (Alakoski 2007: 280)

The narrator uses first-person plural forms frequently. They are rare in dialogue. Thus, while the first-person narration and the dialogue - with the exception of the vulgarisms mentioned above - are not morphosyntactically marked as colloquial in the source text, the narration is less standard than the dialogue in the translation. This outcome is accentuated by the fact that, in Finnish, the difference between formal and casual registers is largely morphological. Therefore, the distance between the two instances of "I", the narrating "l" and the experiencing "I", appears to be less marked in the translation.

\section{From voices to focalization}

Heterolingualism seems to be the norm for "migrant," "minor," and "minority" literatures such as the French "Beur novel" (Hargreaves 1990) and "Black English writing" (Buzelin 2006). But each constellation of heterolingualism is unique. In the previous section, I analyzed the ways in which language variation 
and its translation affect the relations between the characters and the narrator in the four novels under scrutiny. The unique nature of each novel explains the somewhat contradictory results of the analysis. In this section, I will extend the analysis of voices towards focalization or point of view. Although identifying the instances to whom speech and thought in the novel can be attributed (voices) differs from identifying the instances who see (focalization or point of view), the two are linked.

For literary translators, one of the most challenging aspects of their work is to translate the "feel" of the novel. According to Simpson (1993: 7), that feel is created essentially through point of view, i.e. focalization (a term commonly used since the publication of Genette's Figures III in 1972). Most narratologists today operate within a two-ended spectrum of focalization: internal and external (Fleischman 1990: 219), although more complex categorizations have also been presented (e.g. Simpson 1993). In external focalization, the only information that is available is related to the immediate spectacle of the scene, and no information regarding the thoughts of any of the characters is given. In internal focalization, which is a typical feature of the modern psychological novel, the narrator knows as much as the character and reveals only things that the focalized character knows or perceives (Genette 1972, 1983).

Genette's (1972: 206-211) concept of focalization is based on the difference between narrative mode (who is the personage whose point of view orients the narration, who sees?) and voice (who is the narrator, who speaks?). The two are entangled: even though point of view itself is nonverbal, it must be conveyed through linguistic means (Fleischman 1990: 216). For example, Rimmon-Kenan (1983: 72-73) notes that events may be reported from the point of view of the child in a first-person narrative, but the vocabulary may reveal that the narrator is an adult. Similarly, Fleischman (1990: 219-235) observes that if the temporal and psychological distance between the narrating "I" and the experiencing "I" is minimal (which is the case in Camus' The Stranger), or if the perception through which the story is rendered is that of the narrating "l" rather than the experiencing "I" (which is the case of marked focalization in Proust's In Search for Lost Time), focalization can be external even in first-person narratives. According to Fleischman, tense-aspectual features are important means in creating such marked focalization in first-person narratives. Hence, while firstperson narratives mimic confessions and (pseudo)-autobiographies (Fleischman 1990: 234; Fludernik 1996: 90), this does not automatically imply internal focalization.

Genette (1972: 194, 209-210, 214, 236 and 1983: 71) actually argues that firstperson narratives are naturally inclined towards external focalization, whereas third-person narratives are predisposed to internal focalization. This is because third-person narrators have a natural tendency to display discretion and respect towards their characters. In first-person narratives, conversely, the narrator has no duty of discretion towards him or herself: the only duty of respect concerns his or her current information as a narrator rather than past information as the protagonist. Consequently, although the narrator and the hero are identical in first-person narratives, pure internal focalization can only be found in interior 
monologue. In third-person narratives, free indirect discourse is the tool par excellence through which internal focalization is expressed. Indeed, interior monologue and free indirect discourse are functionally analogous (Fleischman 1990: 234).

As Klinger (2015) has shown, linguistic hybridity and the relation between standard and non-standard usage are important components in the coconstruction of focalization. Thus, the focalization shifts that take place in the translations of the four novels analyzed in this article can be explained by the continuum from standard to non-standard language. This continuum is intervowen with other continua: the continuum between spoken and written language and the spectrum ranging from non-marked variation to variation that is strongly marked regionally and/or socially.

In Niemi's Popular Music from Vittula and Alakoski's Svinalängorna, the fact that the foreign language of the source text is the language of the target text renders the translation process more complex, while at the same time increasing the risk of the indexical relation of Otherness becoming that of Sameness in the translation (cf. Grutman 2006: 22). For example, in Niemi's novel, the foreign language of the source text corresponds to a variety identified as a regional dialect of Finnish in the translation. This dialect has quite an extensive history of literary representation in the works of writers such as Timo K. Mukka and Rosa Liksom. In the translation, the representation of dialectal usage spreads towards utterances that are not marked as foreign in the source text. The same phenomenon occurs in the translation of Alakoski's novel, but in this case the representation of non-standard speech affects the narration rather than the direct speech of the characters. The narrator's language use is only slightly colloquial in the source text. But the abundant use of mixed forms of speech and thought representation, free direct discourse and interior monologue in particular (cf. example 9), often consisting of vulgarisms, increases the colloquial flavor of the narration. This may have motivated the translation's more pronounced representation of colloquial language in the narration. Another reason may reside within the narrative structure of the novel. The final temporal convergence is projected into the past, as if the narrator were a teenager. In the translation of Niemi's novel, the accentuated dialect representation of the main character's speech therefore increases the distance between the narrating "I" and the experiencing "I", which appears to suggest a (very) minor shift towards internal focalization. In the translation of Alakoski's novel, however, this distance decreases, and the narrating "I" and the experiencing "I" seem to converge, which indicates increased internal focalization on the main character and decreased internal focalization on other characters.

Among the novels analyzed here, the distance between the narrator and the protagonist is most pronounced in Bakhtiari's novel Kalla det vad fan du vill, in which the third-person narrator uses mostly standard language, whereas the speech of most characters is marked as non-standard in varying degrees. Clear boundaries between different categories of speech and thought representation probably explain why there are no significant shifts affecting focalization in the translation. Although the presence of different languages and varieties is 
particularly strong in Bakhtiari's novel, these are clearly marked both in the source text and the translation: almost every character's speech is nonstandard. As a result, both in the original and in translation, Bakhtiari's novel reads as a highly polyphonic text in the Bakhtinian understanding of the notion. A translation strategy dismissing this plurality of voices would have completely altered the novel's narrative framework.

In Khemiri's novel Ett öga rött, the distance between the narrator and the protagonist is minimal, and the narration occasionally oscillates towards interior monologue. In the translation of Khemiri's novel, in contrast, the distance between the two instances of "l" becomes more accentuated because the syntax of the translation is standard (although at times idiosyncratic): mostly lexical and very few other means are used to render the non-standard quality of the narration. While the focalization of the source text is mostly internal, with the exception of a few instances in which the diary writer refers to himself in the third person, the translation oscillates between external and internal focalization.

These findings are consistent with previous investigations of the translation of speech and thought representation techniques and point of view: focalization or point of view and the distribution of speech and thought representation techniques are often altered in translation, especially when mixed types of discourse are present. Structural differences between languages may explain such shifts (see e.g. Gallagher 2001; Rouhiainen 2001; Taivalkoski-Shilov 2006; Kuusi 2006; Bosseaux 2007: 60-61). Translation universals, such as explicitation, simplification, normalization/conservatism, leveling out, sourcelanguage interference, untypical collocations, and underrepresentation of unique target-language elements (see e.g. Baker 1996; Tirkkonen-Condit 2004; Mauranen 2006) have also been presented as potential explanations. However, scholars have criticized translation universals for failing to take into account the contingency of translation norms (Paloposki 2002). Thus, literary and translational norms have been proposed as other possible explanations for shifts affecting focalization and speech and thought representation in translations (Toury 1980: 116; Taivalkoski-Shilov 2006).

Indeed, since the shifts identified in the translations of the four novels are not systematic, it is necessary to continue the analysis of these shifts within a larger framework of the social context of translation. This will be the topic of the next section.

\section{Authenticity and boundaries}

In their extensive overview of colloquial language in Finnish literature, Tiittula and Nuolijärvi $(2014: 143,233)$ list three tendencies in contemporary Finnish literature (see also Tiittula's and Nuolijärvi's article in this special issue): the normalization of the representation of spoken language in both character and narrator discourse; increased mixing of different registers and increased presence of standard language in the characters' speech; and increased representation of spoken language in general, with the representation of dialect 
becoming more "authentic." Colloquial language and slang are much more prevalent in youth literature, and an entire novel, narrated by a young narrator, may be written in a colloquial style that cannot be linked to a particular regional dialect.

Interviews with five editors of translated fiction revealed that their attitudes towards colloquial and dialectal language in literature varied from total tolerance to strong reluctance (ibid. 255). Quoting interviews with the translators and pieces written by them in professional publications, Tiittula and Nuolijärvi also provide information about the choices made by the translators of the four novels analyzed in this article. Thus, after discussion with the editor, the translator of Popular Music from Vittula decided to add dialectal and other colloquial features such as repetitions to the translation, because otherwise the translation would not have had the same effect as the source text (ibid. 364). As for Alakoski's novel, they note that while the source text is bilingual, the translation became monolingual (ibid. 369-371). According to the translator of Khemiri's novel (ibid. 377), using mostly standard Finnish and only lexical means to render the nonstandard quality of language was an inevitable choice because, according to the translator, there is no "equivalent immigrant slang" in Finnish. The translator of Kalla det vad fan du vill said that she was cautious with dialects in the translation, for readers would have found a faithful translation "too overwhelming." However, she tried to familiarize herself with "immigrant Finnish" by watching television shows in which there were migrants and making lists of the typical features of their speech and "grammatical errors" (ibid. 373-376).

While there are studies discussing the possible existence of new multiethnic youth varieties of Finnish, for example in the Eastern suburbs of Helsinki (Lehtonen 2011), "immigrant Finnish dialects" have not appeared in Finnish literature, which has been a disappointment to some literary critics. At the same time, there is a long tradition of literary representation of other varieties in Finnish literature. Thus, a tradition of literary representation of Northwestern dialects of Finnish spoken on both banks of the Torne River Valley and different traditions of the representation of other dialects and sociolects, including slang, were available to the translators of Niemi's and Alakoski's novels. Both novels also depict the loss of the mother tongue. Language attrition, language shift, and broken linguistic identity were also key themes in Antti Jalava's 1980 Asfaltblomman, the first major "migrant novel" in Sweden. It played an important role in introducing the social and linguistic reality of Finnish immigration to Sweden in the 1960s and 1970s to general discussion, including themes such as language and identity, forced assimilation by the school system, and discrimination based on ethnic origin. Much of this discussion revolved around the loaded term of semilingualism, i.e. the alleged lack and loss of native language among migrant children. Indeed, Jalava's 1980 Asfaltblomman provides several accounts of semilingualism among Finnish migrants in Sweden, both in reported speech, mixed forms of speech and thought representation, and narratorial discourse. Today, this discussion is over, as is mass migration of Finns to Sweden. Consequently, while Alakoski's novel is, among other things, a novel about Finnish immigration to Sweden, critics have 
preferred to stress its role as a portrait of childhood destroyed by alcoholism, domestic violence, poverty, and shame.

Khemiri's and Bakhtiari's novels, on the other hand, have been read as novels about immigration and linguistic identity. Rather than portraits of the loss of a language, these novels read as celebrations of heterolingualism and the linguistic creativity resulting from language contact. When Khemiri's novel was published, some criticized the blatant deviations from the norms of written language. Most literary critics, however, welcomed the novel with open arms. The author himself noted that he could not have written the story of Halim, the main character, without using "his language," and linked the debate about the novel's language to the changing faces of Swedish identity and the issue of authenticity (Gröndahl 2007: 27; Bengtsson 2008: 3, 19). And while the author himself has argued that Halim's language is a literary construct and an idiolect rather than a discreete sociolect (af Kleen 2006), the novel was widely interpreted as a social documentary and authentic testimony and became the representative par excellence of the "Swedish immigrant novel" written in "immigrant Swedish." The sociolect identified in Khemiri's novel has been called, among others, förortssvenska, 'suburb Swedish' (the word suburb referring to areas with a high concentration of social housing units), Rinkebysvenska (from the name of a suburb in Stockholm that has become a paragon of districts with a high concentration of migrants and various linked social phenomena), kebabsvenska (referring to the fact that kebab joints are typically run by Middle Eastern migrants), miljonsvenska (referring to the 1960s project of building 1 million new dwellings and the fact that many of these high-rise concrete buildings have been populated by migrants), and blattesvenska (referring to a derogatory term for 'migrant'). These alleged varieties have also been associated with Bakhtiari's novel.

Thus, in Swedish literary culture, the emergence of the "migrant novel" as a new literary genre has been widely acknowledged, and many critics have linked it to identity politics and immigration policy in general, including debates about the changing notions of culture, language, and ethnicity (Gröndahl 2007: 21). However, Gröndahl (ibid. 27) also argues that while Niemi proudly presents himself as a representative of the Torne River Valley, authors like Khemiri do not want to appear as representatives of migrants. Indeed, as Kongslien (2013: 126) notes, writers such as Greek-born Theodor Kallifatides, who has published over 30 books in Swedish, have expressed indignation over the fact that they are still regarded as "immigrant writers." Similar phenomena have been observed in other contexts such as French "Beur writing": when these novels started to appear, academics and librarians alike were not sure whether they should be catalogued as French or North African literature (Hargreaves 1996, Aitsiselmi 1999).

Nilsson (2010, 2012 and 2013) also notes that ethnicity has been the central focus in discussions about Swedish "immigrant and minority literature," both within and outside the Academe. According to him (2012), Khemiri's and Bakhtiari's novels are best understood as a critical dialogue about Sweden as a multicultural society and a satire and critique of "Swedish immigrant literature," 
including the language use observed within it. This viewpoint is based on the argument that focusing on ethnicity "produces othering and exoticizing" and "contributes to the racialization of non-Swedish ethnicities" (Nilsson 2010: 201, 208-216; 2013: 47-48; see also Behschnitt 2013: 194-195). Nilsson's arguments are largely based on Amodeo's, Mohnike's, and Beschnitt's observations on Swedish and German migrant writing (Amodeo 1996; Behschnitt \& Mohnike 2006; Mohnike 2007; Behschnitt 2010). Thus, "immigrant literature" is a discursive category in which the production and reception of texts relies largely on paratextual facts such as the writer's foreign-sounding name (see also Tuomarla 2013: 196). For that reason, "migrant writers" are expected to expose their immigrant identity and experience in their texts, which are subsequently read as a source of information and as biography. Khemiri's and Bakhtiari's novels are central representatives of this genre in Sweden. In addition to paratextuality, Nilsson (2010: 203; 2013: 47-48) argues that authenticity can be constructed thematically by representing an "immigrant problematic" and stylistically through language use, interpreted as representing "immigrant Swedish." Overall, stereotypes rather than facts function as tools in the discursive construction of this genre. However, the criticism that both critics and writers have expressed against the discursive construction of "immigrant literature" in Sweden has resulted in the "death" of the immigrant writer, according to Nilsson (2013).

Along these lines, authenticity emerges as a key concept defining the genre of "migrant novels" and a key problem faced by the translators in the representation of sociolinguistic variation. Authenticity has also been one of the cornerstones of sociolinguistics and its predecessors: the search for "uncorrupt," "original" native speakers of dialects and sociolects pertaining to specific groups has oriented dialectologists and sociolinguists of the variationist paradigm alike (Coupland 2010). However, in recent sociolinguistic research, authenticity and related concepts such as the native speaker and the boundaries between different languages and language varieties have been questioned (see e.g. Eckert 2003; Bucholz 2003; Coupland 2003, 2010 and 2014; Heller 2014). This contestation is rooted in the criticism directed against formalist notions of language in sociolinguistics (Cameron 1990). Indeed, sociolinguistics and linguistic anthropology have rediscovered Bakhtin's (1986) and Voloshinov's (1986) ideas, according to which language is essentially a dynamic process and a hybrid construction rather than a fixed entity.

Interestingly, the rediscovery of hybridity in sociolinguistics appears to parallel the discovery of hybridity and the contestation of boundaries in postcolonial and poststructuralist translation theory. Postcolonial and poststructuralist theory consider the "original" to be an impossible translation (e.g. Johnson 1985), on the one hand, and writing and translation a fecund site of creation, on the other hand. Hybridity is a key concept in such approaches. For example, Bhabha (1996: 58), echoing Bakhtin's views on hybridity and doubleness in language, argues that "discursive doubleness" may open up a space capable of engendering a new "speech act" (in an understanding of the term that differs from speech act theory), including a new site for "writing the nation" (Bhabha 1990: 297). Similarly, Gentzler (2002: 217) argues that, in poststructural 
translation, "hybrid sites of new meaning open up; new borders are encountered and crossed, often with surprisingly creative results." Therefore, in a postcolonial context, translation implies a reflection about the nature, role, and position of the translator and their readership (Buzelin 2006: 110), for translation does not just happen between cultures, it constitutes them (Gentzler 2008: 5).

While multilingualism in literature and translation is not a new phenomenon (see e.g. Grutman 1998), Meylaerts (2006: 1) argues that the recent focus on multilingualism in translation studies is related to the fact that "its modalities have changed due to recent technological, political, and other developments." Buzelin (2006: 92), in contrast, thinks that Bakhtinian and postcolonial theories have prompted this shift. Thus, scholars, critics, and editors have started to pay attention to hybridity, multilingualism, and orality. This can be explained by the fact that there are new literary markets responsive to hybridity and more authors from formerly colonized areas where linguistic and ethnic hybridity is commonplace.

Sociolinguists know that in terms of global language practices, hybridity is the rule rather than an exception (Blommaert 2006: 169). Nevertheless, authenticity, strict boundaries, and the concept of the native speaker are still the cornerstones of language professions, and of translation and interpreting in particular: hybridity may be celebrated, but it is difficult to escape from boundaries. The societal and scholarly discussion about the "Swedish migrant novel" focuses on the novelty constituted by hybridity. This is visible not only in the personal identity of the characters and the author but also in language use. Nonetheless, this very celebration of hybridity is accompanied by the search for, and identification of, a distinct variety of language purportedly used by migrants. A more detailed analysis of critical approaches to authenticity may explain this mechanism.

Critical positions towards authenticity have centered on the links between authenticity and essentialism, i.e. "the position that the attributes and behavior of socially defined groups can be determined and explained by reference to cultural and/or biological characteristics believed to be inherent of that group" (Bucholz 2003: 400). Such essentialism is linked to the concepts of iconization, recursiveness, and erasure introduced by Gal and Irvine (1995, 2000). Thus, linguistic features associated with a group and perceived as differences are interpreted as being iconic of the identities of the speakers. A mechanism of selection then emerges, through which certain distinctions and oppositions are maintained and created and others dismissed. Language ideologies can be identified as a major force governing this process. Other theorizations of this process include Agha's (2003) concept of enregisterment, a phenomenon by which a way of using language is distinguished among other usages and becomes a register that is socially recognized.

As a result of such essentializing practices, communicative repertoires become indexically linked to repertoires of identities (Cameron 2003: 448-449; Blommaert 2006: 167-168). Such processes explain how, for example, African American Vernacular English has been correlated mostly with the socio- 
economic features of the speaker population, rather than with the linguistic properties of this variety (Mufwene 2001: 23). But as Buzelin (2006: 96-97) and Määttä (2004) observe, literature is not immune to such processes. In fact, the "Swedish migrant novel" is based on a process in which features associated with migrant usages of language have become enregistered and iconized as a socially recognized language variety. Stroud (2004) and Milani (2010) have analyzed naming practices linked to the emergence of this variety as ideological and imaginary constructions which function as tools to create boundaries between that which is ethnically Swedish and that which is not. Consequently, while hybridity is almost invariably mentioned by literary critics and academic scholars studying these phenomena, and while some of these novels have also been read as "revolutionary speech acts" (e.g. Lacatus 2007), the variety identified by labels such as "migrant Swedish" is the tool through which this hybridity and the transformative acts attached to it are materialized.

On a personal level, multilingualism is best understood as a hybrid repertoire shaped by a life-long linguistic trajectory, rather than as a repository of stable, bounded entities composing a plurality of monolingual varieties. As a matter of fact, heterolingualism is a feature of voices and speakers rather than a feature of languages (Blommaert 2006: 167-173). Therefore, while identity is best understood as a position and a process constructed within representation (Hall 1996: 2,$4 ; 1997: 33$ ), identity becomes fixed when it is inscribed in the language use of a novel, and when heterolingualism and hybridity are linked to particular language varieties.

\section{Concluding remarks}

As Folkart (1991: 433) remarks, the representation of non-standard language can be an internal necessity for the creator of the source text. Such emotional links constitute a component of the "feel" of the novel that is difficult to translate. Nonetheless, Lefevere (2000: 240) has identified misunderstandings and misconceptions, or refractions, as a major explanation for the influence and exposure that a writer's work may gain: writers and their work "are refracted through a certain spectrum" and interpreted against a given background. As my analysis has shown, shifts affecting speech and thought representation and focalization, occasioned by the translation process, can be attributed to a wide, seemingly unsystematic array of textual factors. Refractions related to larger contextual factors thus emerge as a potential explanation for the "feel" of a text and its translation.

A coming-of-age story written by a person who has a name that can be associated with a minority or migrant population is typically read as a portrait and documentary of the minority or migrant experience. This process includes the search for features representing authentic minority or migrant language use in the text. Furthermore, the text is read as an autobiography in which not only the instances of the character and the narrator but also that of the author are conflated, for the author is interpreted as "knowing" the people and the environment of the novel's diegesis in precisely the same way the narrator does 
(cf. Genette 1972: 226; Cohn 2000; Gavins 2007). Even in third-person narratives such as Bakhtiari's novel, the narrator and the author alike are interpreted as being present in the story and telling their own story, as if the third person were only a masquerade for the first person. Therefore, while the ethnicminority perspective is just one of the many possible dimensions on which the novel's interpretation could be anchored, it invariably becomes the predominant one: we only identify one voice and one central perspective to which "linguistically subjective elements and constructions are referred" (Banfield 1991: 23-24). Paratextual elements such as the author's name, the book cover, and the title of the book strengthen this interpretation. For example, Bakhtiari's book is translated as Mistään kotosin ('Coming from nowhere') in Finnish. The cover of the Swedish paperback depicts a detail from a gray urban landscape with the book title in red and ornaments above and below. The cover of the Finnish paperback, in contrast, portrays a dark-haired young woman wearing a headscarf or a veil to cover the lower part of her face, and the title is composed of multicolored letters, some of which show details from Oriental rugs.

Paratextual factors of this kind accentuate the willing suspension of disbelief (Stearns 2014), pushing the readers to suspend their disbelief regarding the fictional nature of the story, its characters, and the language varieties used in the novel.

In the sense of multiple possible voices representing multiple possible contexts and interpretations, polyphony is a quintessential feature of language. But we all interpret utterances, texts, and all language use differently - different readings and misunderstandings are part of our everyday life. Divergent readings are a particularly salient feature of written communication because the tools for creating shared contexts between the producer of the text and its recipients are limited. Nevertheless, certain interpretations and representations are more salient than others because they are culturally or discursively more prominent certain voices are recognized whereas others are not heard or remain secondary. I argue that alongside cultural or discursive prominence, this selection of voices is related to our cognitive limitations: prototypical interpretations and representations emerge because otherwise we would not be able to make sense of the chaotic world around us. Communication would be quite complicated if we had to consider all possible interpretations equally and check their accuracy, i.e. understand all indexical meanings related to different voices and the contexts they activate - and act accordingly.

The reading of a literary text is subject to the same limitations as any interpretation of language use. And yet, literary scholars, literary linguists, translation scholars, and translators probably have more sophisticated skills for deciphering polyphony than most other readers. For example, we may be able to distinguish the translator's voice and discursive presence (Hermans 1996: 27). But we are not able to distinguish the indexical complexities of this and other voices in their entirety. This article is not an exception, although its aim is to provide a critical analysis taking into account as many perspectives as possible. 
The difficulty of deciphering polyphony (in the wider sense of the term) and the predominance of certain interpretations over others are also related to the fact that boundaries and their inevitable corollary - standards - are meaningful to people. What is at stake as a quintessential criterion for genre membership in the "ethnic coming-of-age story" is the presence of language variation and distinct language varieties related to ethnicity. This is why the translator is under considerable pressure to "pass" as an authentic reproducer of the varieties evoked in the source text.

Conceptualizing language and language varieties as bounded entities is perhaps one of the most fundamental language ideologies, for it is linked to the construction and recognition of identities. The identity connection is perhaps also the reason why we do not easily perceive these language ideologies and the practices or discourses through which they are reified. In fact, I argue that due to our cognitive limitations and inability to process and interpret heteroglossia and polyphony in all their complexity, we inadvertently consider languages and language varieties as entities separated by boundaries. Such boundaries - created by differences and distinctions - can be conceived both as a condition for the commodification of language and as a consequence of that commodification. Thus, one cannot write, publish, and sell a novel centering on the coming-of-age process of a migrant or a representative of an ethnic or national minority - one cannot occupy a subject position from which this particular genre pertaining to the discourse of hybridity potentially emanates unless one is a member of such a group. In other words, the subject position of the real world and the position formed by the novel's diegesis have to be identical (cf. Simpson 1993: 32).

At the same time, the publication (and translation) of such a novel reinforces linguistic boundaries that are used to create distinctions, for inscribing a usage immersed in a complex network of ideologies into a written text is a powerful act and has a material effect just like any other discursive strategy (cf. Foucault 1971: 11; 1984: 109). Here, material effects refer to the emergence of categories, boundaries, and objects such as the literary genre, migrant and minority languages, or migrant and minority language varieties under scrutiny in this article. Consequently, the reception and the translation of multicultural coming-of-age stories not only contribute to the construction of the "Other" but also to the materialization of the very tool with which that construction is performed - "migrant language."

\section{Acknowledgements}

The author would like to thank the editors and the anonymous referees for valuable suggestions on an earlier draft of this paper. 


\section{Primary Sources}

Alakoski, Susanna (2006). Svinalängorna. Stockholm: Bonniers.

--- (2007). Sikalat. Trans. Katriina Savolainen. Helsinki: Schildts.

Bakhtiari, Marjaneh (2005). Kalla det vad fan du vill. Stockholm: Ordfront.

--- (2011 [2007]). Mistään kotosin. Trans. Leena Peltomaa. Helsinki: Otava.

Khemiri, Jonas Hassen (2003). Ett öga rött. Stockholm: Norstedts.

--- (2004). Ajatussulttaani. Trans. Outi Menna. Helsinki: Johnny Kniga.

Niemi, Mikael (2000). Populärmusik från Vittula. Stockholm: Norstedts.

--- (2001). Populäärimusiikkia Vittulajänkältä. Trans. Outi Menna. Helsinki: Like.

--- (2003). Popular Music from Vittula. Trans. Laurie Thompson. New York: Seven Stories Press.

\section{References}

af Kleen, Björn (2006). Hassen Khemiri vill uppfinna sig själv, Sydsvenskan February 4, 2006. Available at: http://www.sydsvenskan.se/2006-02-04/hassen-khemiri-villuppinna-sig-sjalv (accessed 17 June 2016)

Agha, Asif (2003). The Social Life of Cultural Value, Language \& Communication 23, 231-273.

Aitsiselmi, Farid (1999). Métissage linguistique dans le roman beur, Cahiers 5(3), 11-22.

Arrojo, Rosemary (1994). Fidelity and the Gendered Translation, TTR. Traduction, terminologie, rédaction 7(2), 147-163.

Amodeo, Immacolata (1996). Die Heimat heißt Babylon. Zur Literatur ausländischer Autoren in der Bundesrepublik Deutschland. Opladen: Westdeutscher Verlag.

Baker, Mona (1996). Corpus-based Translation Studies. The Challenges that Lie Ahead. Terminology, LSP and Translation. Studies in Language Engineering in Honour of Juan C. Sager, ed. Harold Somers. Amsterdam: Benjamins, 175-186.

Banfield, Ann (1991). L'Écriture et le non-dit, diacritics 21(4), 21-31.

Bakhtin, Mihail (1986). Speech Genres and Other Late Essays. Trans. V. W. McGee, eds. Caryl Emerson \& Michael Holquist. Texas: University of Texas Press.

Behschnitt, Wolfgang (2010). The Voice of the "Real Migrant". Contemporary Migration Literature in Sweden. Migration and Literature in Contemporary Europe, eds. Mirjam Gebauer \& Pia Schwarz Lausten. Munich: Martin Meidenbauer, 77-92.

--- (2013). The Rhythm of Hip Hop. Multi-ethnic Slang in Swedish Literature after 2000. Literature, Language, and Multiculturalism in Scandinavia and the Low Countries, eds. Wolfgang Behschnitt, Sarah De Mul \& Liesbeth Minnaard. Amsterdam: Rodopi, 175-195.

Behschnitt, Wolfgang \& Mohnike, Thomas 2006. Bildung und Alteritätskonstitution in der jüngsten schwedischen Migrantenliteratur. Bildung und Anderes. Alterität in Bildungsdiskursen in den skandinavischen Literaturen, eds. Wolfgang Behschnitt \& Christiane Barz. Würzburg: Ergon, 201-229. 
Bengtsson, Henrik (2008). Att göra västvärldens bild till sin - en postcolonial läsning av Ett Öga Rött. Lunds Universitet: Litteraturvetenskapliga institutionen.

Berman, Antoine (2000). Translation and the Trials of the Foreign. Trans. Lawrence Venuti. The Translation Studies Reader, ed. Lawrence Venuti. London: Routledge, 276-289.

Berthele, Raphael (2000). Translating African-American Vernacular English into German: The Problem of "Jim" in Mark Twain's Huckeleberry Finn, Journal of Sociolinguistics 4(4), 588-613.

Bhabha, Homi K. (1990). DissemiNation. Time, Narrative, and the Margins of the Modern Nation. Nation and Narration, ed. Homi Bhabha. New York: Routledge, 291322.

--- (1996). Culture's In-Between. Questions of Cultural Identity, eds. Stuart Hall \& Paul du Gay. London: Sage, 53-60.

Blommaert, Jan (2006). How Legitimate Is My Voice? A Rejoinder, Target 18(1), 163176.

Bosseaux, Charlotte (2007). How Does It Feel? Point of View in Translation. The Case of Virginia Wolf in French. Amsterdam: Rodopi.

Brisset, Annie (1990). Sociocritique de la traduction. Théâtre et altérité au Québec (1968-1988). Longueuil: Préambule.

Bucholz, Mary (2003). Sociolinguistic Nostalgia and the Authentication of Identity, Journal of Sociolinguistics 7(3), 398-416.

Buzelin, Hélène (2006). Traduire I'hybridité littéraire. Réflexions à partir du roman de Samuel Selvon: The Lonely Londoners, Target 18(1), 91-119.

Cameron, Deborah (1990). Demythologizing Sociolinguistics. Why Language Does Not Reflect Society. Ideologies of Language, eds. John E. Joseph \& Talbot J. Taylor. London: Routledge, 79-93.

--- (2003). Gender and Language Ideologies. The Handbook of Language and Gender, eds. Janet Holmes \& Miriam Meyerhoff. Oxford: Blackwell, 447-467.

Cohn, Dorrit (2000). Discordant Narration, Style 43(2), 307-316.

Coupland, Nikolas (2003). Sociolinguistic Authenticities, Journal of Sociolinguistics 7(3), 417-431.

--- (2010). The Authentic Speaker and the Speech Community. Language and Identities, eds. Carmen Llamas \& Dominic Watt. Edinburgh: Edinburgh University Press, 99112.

--- (2014). Language, Society and Authenticity. Indexing Authenticity. Sociolinguistic Perspectives, eds. Véronique Lacoste, Jakob Leimbruger \& Thiemo Breyer. Berlin: Mouton de Gruyter, 14-39.

Ducrot, Oswald (1980). Le dire et le dit. Paris: Minuit.

Eckert, Penelope (2003). Elephants in the Room, Journal of Sociolinguistics 7(3), 392397.

Findlay, Bill (1996). Translation into Dialect. Stages of Translation, ed. David Johnston. Bath: Absolute Classics, 199-217. 
Fleischman, Suzanne (1990). Tense and Narrativity. From Medieval Performance to Modern Fiction. Austin: University of Texas Press.

Fludernik, Monika (1996). An Introduction to Narratology. Trans. Patricia HäuslerGreenfield \& Monika Fludernik. London: Routledge.

Folkart, Barbara (1991). Le Conflit des énonciations. Traduction et discours rapporté. Québec: Balzac.

Foucault, Michel (1971). L'ordre du discours. Paris: Gallimard.

--- (1984). The Order of Discourse. Trans. Ian McLeod. Language and Politics. Ed. Michael J. Shapiro. New York: New York University Press, 108-138.

Fowler, Roger (1977). Linguistics and the Novel. London: Methuen.

Gal, Susan \& Irvine, Judith T. (1995). The Boundaries of Languages and Disciplines. How Ideologies Construct Difference, Social Research 62(4), 967-1001.

--- (2000). Language Ideology and Linguistic Differentiation. Regimes of Language. Ideologies, Polities, and Identities, ed. Paul V. Kroskrity. Santa Fe: School of American Research Press, 35-84.

Gal, Susan \& Woolard, Kathryn A. (1995). Constructing Languages and Publics. Authority and Representation, Pragmatics, 5(2), 129-138.

Gallagher, John D. (2001). Le discours indirect libre vu par le traducteur. Oralité et traduction, ed. Michel Ballard. Arras: Artois Presses Université, 209-244.

Gavins, Joanna (2007). Text World Theory. An Introduction. Edinburgh: Edinburgh University Press.

Genette, Gérard (1972). Figures III. Paris: Seuil.

--- (1983). Nouveau discours du récit. Paris: Seuil.

Gentzler, Edwin (2002). Translation, Poststructuralism, and Power. Translation and Power, eds. Maria Tymoczko \& Edwin Gentzler. Amherst: University of Massachusetts Press, 195-218.

--- (2008). Translation and Identity in the Americas. New Directions in Translation Theory. London: Routledge.

Gröndahl, Satu (2007). Identity Politics and Construction of "Minor" Literatures. Multicultural Swedish Literature at the Turn of the Millennium, Multiethnica 30, 2129.

Grutman Rainier (1998). Multilingualism and Translation. Routledge Encyclopedia of Translation Studies, ed. Mona Baker. New York: Routledge, 157-160.

--- (2006). Refraction and Cognition. Literary Multilingualism in Translation, Target 18(1), 17-47.

Hall, Stuart (1996). Introduction. Who Needs Identity? Questions of Cultural Identity, eds. Stuart Hall \& Paul du Gay. London: Sage, 1-17.

--- (1997). Culture and Power. Radical Philosophy 86, 24-41. (An interview conducted by Peter Osborne and Lynne Segal.)

Halliday, M.A.K. (1978). Language as Social Semiotic. The Social Interpretation of Language and Meaning. London: Arnold. 
Hargreaves, Alec G. (1990). Language and Identity in Beur Culture. French Cultural Studies 1(1), 47-58.

--- (1996). Writers of Maghrebian Origin in France. French, Francophone, Maghrebian or Beur? African Francophone Writing. A Critical Introduction, eds. Laïla Ibnlfassi \& Nicki Hitchcott. Oxford: Berg, 33-43.

Hatim, Basil \& Mason, lan (1997). Translator as Communicator. New York: Routledge.

Heller, Monica (2014). The Commodification of Authenticity. Indexing Authenticity. Sociolinguistic Perspectives, ed. Véronique Lacoste, Jakob Leimbruger \& Thiemo Breyer. Berlin: Mouton de Gruyter, 136-39.

Heller, Monica \& Duchêne, Alexandre (2012). Pride and Profit. Changing Discourses of Language, Capital, and Nation-State, ed. Alexandre Duchêne \& Monica Heller. New York: Routledge, 1-21.

Hermans, Theo (1996). The Translator's Voice in Translated Narrative, Target 8(1), 2348.

House, Juliane (2006). Text and Context in Translation, Journal of Pragmatics 38, 338358.

Johnson, Barbara (1985). Taking Fidelity Philosophically. Difference in Translation, ed. Joseph F. Graham. Ithaca, N.Y.: Cornell University Press, 142-148.

Klinger, Susanne (2015). Translation and Linguistic Hybridity. Constructing World-View. New York: Routledge.

Kongslien, Ingeborg (2013). The Scandinavian "Migrant Novel" - A New National Narrative and a Cosmopolitan Tale. Le Roman migrant au Québec et en Scandinavie / The Migrant Novel in Quebec and Scandinavia. Performativité, conflits signifiants et créolisation / Performativity, Meaningful Conflicts and Creolization, ed. Svante Lindberg. Frankfurt/M.: Peter Lang, 125-139.

Kuusi, Päivi (2006). Explicitation as Simplification. Universal Tendencies in the Translation of FID. Free Language, Indirect Translation, Discourse Narratology: Linguistic, Translatological and Literary-Theoretical Encounters, eds. Pekka Tammi \& Hannu Tommola. Tampere: Tampere University Press, 89-113.

Lacatus, Corina (2007). Negotiating the Other. Language, Ethnicity, and Identity in Contemporary Sweden. Ph.D. dissertation. University of California, Los Angeles.

Lane-Mercier, Gillian (1997). Translating the Untranslatable. The Translator's Aesthetic, Ideological and Political Responsibility, Target 9(1), 43-68.

Leech, Geoffrey N. \& Short, Michael H. (1981). Style in Fiction. A Linguistic Introduction to English Fictional Prose. London: Longman.

Lefevere, André (2000). Mother Courage's Cucumbers. Text, System and Refraction in a Theory of Literature. The Translation Studies Reader, ed. Lawrence Venuti. London: Routledge, 239-255.

Lehtonen, Heini (2011). Developing Multiethnic Youth Language in Helsinki. Ethnic Styles of Speaking in European Metropolitan Areas, eds. Friederike Kern \& Margret Selting. Amsterdam: John Benjamins, 291-318.

Määttä, Simo (2004). Dialect and Point of View. The Ideology of Translation in The Sound and the Fury in French, Target 16(2), 319-339. 
Mason, Ian (2014). Discourse and Translation. A Social Perspective. Translation. A Multidisciplinary Approach, ed. Juliane House. Basingstoke: Palgrave Macmillan, 36-55.

Mauranen, Anna (2006). Translation Universals. Encyclopedia of Language \& Linguistics, ed. Keith Brown. Amsterdam: Elsevier Science, 93-100.

McHale, Brian (1994). Child as Ready-Made. Baby-Talk and the Language of Dos Passos's Children in U.S.A. Infant Tongues. The Voice of the Child in Literature, eds. Elizabeth Goodenough, Mark A. Heberle \& Naomi Cokoloff. Detroit: Wayne State University Press, 202-224.

Meylaerts, Reine (2006). Heterolingualism in/and Translation. How Legitimate Are the Other and His/Her Language? An Introduction, Target 81(1), 1-15.

Milani, Tommaso M. (2010). What's in a Name? Language Ideology and Social Differentiation in a Swedish Printed-Mediated Debate, Journal of Sociolinguistics 14(1), 116-142.

Mohnike, Thomas (2007). Der ethnographische Blick. Über den Zusammenhang von Literatur und Kultur als diskursive Kategorien am Beispiel schwedischer Einwandererliteratur der Gegenwart. Transitraum Deutsch. Literatur und Kultur im transnationalen Zeitalter, eds. Adam Jens, Hans-Joachim Hahn, Irena Światłowska \& Łucjan Puchalski. Wroclaw / Dresden: ATUT / Neisse, 237-253.

Mufwene, Salikoko S. (2001). What Is African American English? Sociocultural and Historical Contexts of African American English, ed. Sonja L. Lanehart. Amsterdam: John Benjamins, 21-51.

Nilsson, Magnus (2010). Swedish "Immigrant Literature" and the Construction of Ethnicity, Tijdschrift voor Skandinavistik 31(1), 199-218.

--- (2012). Swedish "Immigrant Literature" and the Ethnic Lens. The Representation of Cultural Diversity in Jonas Hassen Khemiri's Ett öga rött and Marjaneh Bakhtiari's Kalla det vad fan du vill, Scandinavian Studies 84(1), 27-58.

--- (2013). Literature in Multicultural and Multilingual Sweden. The Birth and Death of the Immigrant Writer. Literature, Language, and Multiculturalism in Scandinavia and the Low Countries, eds. Wolfgang Behschnitt, Sarah De Mul \& Liesbeth Minnaard. Amsterdam: Rodopi, 41-61.

Paloposki, Outi (2002). Variation in Translation. Literary Translation into Finnish 18091850. Ph.D. Dissertation. University of Helsinki.

Palokoski, Outi \& Oittinen, Riitta (1998). The Domesticated Foreign. Translation in Context. Selected Contributions from the EST Congress, Granada 1998, eds. Andrew Chesterman, Natividad Gallardo San Salvador \& Yves Gambier. Amsterdam: John Benjamins, 373-390.

Pietikäinen, Sari \& Dlaske, Kati (2013). Cutting across Media Spaces and Boundaries. The Case of a Hybrid, Indigenous Sámi TV Comedy. Sociolinguistica 27(1), 87-100.

Ramos Pinto, Sara (2009). How Important Is the Way You Say It? A Discussion on the Translation of Linguistic Varieties, Target 21(2), 289-307.

Rimmon-Kenan, Shlomith (1983). Narrative Fiction. Contemporary Poetics. London: Methuen. 
Rouhiainen, Tarja (2001). Free Indirect Discourse in the Translation into Finnish. The Case of D.H. Lawrence's Women in Love, Target 12(1), 109-126.

Sánchez, María T. (1999). Translation as a(n) (Im)possible Task. Dialect in Literature, Babel 45(4), 301-310.

Schleiermacher, Friedrich (1963). Über die verschiedenen Methoden des Übersetzens. Das Problem des Übersetzens, ed. Hans-Joachim Störig. Darmstadt:

Wissenschaftliche Buchgesellschaft, 38-70.

Silverstein, Michael (1979). Language Structure and Linguistic Ideology. The Elements. A Parasession on Linguistic Units and Levels, eds. Paul R. Clyne, William F. Hanks \& Carol L. Hofbauer. Chicago: Chicago Linguistic Society, 193-247.

Simpson, Paul (1993). Language, Ideology and Point of View. London: Routledge.

Stearns, Susan E. (2014). Disbelief, Suspension of. Encyclopedia of Deception, ed. Timothy R. Levine. Thousand Oaks, Calif.: Sage.

Stroud, Christopher (2004). Rinkeby Swedish and Semilingualism in Language Ideological Debates. A Bourdieuean Perspective, Journal of Sociolinguistics 8(2), 196-214.

Taivalkoski-Shilov, Kristiina (2006). La Tierce main. Le discours rapporté dans les traductions françaises de Fielding au XVIII ${ }^{e}$ siècle. Arras: Artois Presses Université.

Tiittula, Liisa \& Nuolijärvi, Pirkko (2014). Puheen illuusio suomenkielisessä kaunokirjallisuudessa. Helsinki: SKS.

Tirkkonen-Condit, Sonja (2004). Unique Items - Over- or Under-represented in Translated Language? Translation Universals: Do They Exist?, eds. Anna Mauranen \& Pekka Kujamäki. Amsterdam: John Benjamins, 177-184.

Toury, Gideon (1980). In Search of a Theory of Translation. Tel Aviv University: The Porter Institute for Poetics and Semiotics.

Tuomarla, Ulla (2013). Purge de Sofi Oksanen - un roman migrant? Le Roman migrant au Québec et en Scandinavie / The Migrant Novel in Quebec and Scandinavia : Performativité, conflits signifiants et créolisation / Performativity, Meaningful Conflicts and Creolization, ed. Svante Lindberg. Frankfurt/M.: Peter Lang, 196-211.

Venuti, Lawrence (1995). The Translator's Invisibility. A History of Translation. London: Routledge.

--- (2000). Translation, Community, Utopia. The Translation Studies Reader, ed. Lawrence Venuti. London: Routledge, 467-488.

Voloshinov, A.N. (1986). Marxism and the Philosophy of Language. Trans. Ladislav Matejka \& I.R. Titunik. Cambridge, MA: Harvard University Press.

Woolard, Kathryn A. \& Schieffelin, Bambi (1994). Language Ideology, Annual Review of Anthropology, 23, 55-82. 